\title{
CTG Expansion \& Haplotype Analysis in DM1 Gene in Healthy Iranian Population
}

\author{
Bahareh Shojasaffar, Neda Moradin, Kimia Kahrizi, \\ Ana Maria Cobo, Hossein Najmabadi
}

\begin{abstract}
Myotonic dystrophy type 1 (DM1) is due to an unstable expansion of CTG repeat in the DMPK gene (19q13.3). The CTG repeat is highly polymorphic (5 to 37 ) in healthy individuals. According to the hypothesis that expanded (CTG)n alleles originated from larger normal alleles, there may exist a correlation between the prevalence of DM1 and the frequency of large size normal alleles. Strong linkage disequilibrium between different length alleles and the three biallelic markers, Alu, Hinf1 and Taq1, has been reported. Objective: To determine the distribution of normal alleles, the frequency of larger normal alleles and analysis of the three biallelic markers, in healthy Iranian controls. Material and Methods: Polymerase chain reaction (PCR) was conducted on two hundred unrelated healthy individuals from different ethnic groups living in Iran to determine the size of the alleles. Markers were analyzed by PCR/RFLP on 174 chromosomes from other control healthy individuals. Results: Our data reveals that $23.7 \%$ of alleles had 5 CTG repeats and $7.2 \%$ of alleles had $>18$ CTG repeats. The analysis of haplotypes revealed that $75 \%$ of CTG5 and $80 \%$ of CTG $>18$ had the (+++) haplotype. Conclusion: The frequency of alleles with CTG>18 in Iran is similar to that of Western Europe and Japan.
\end{abstract}

RÉSUMÉ: Expansion CTG et analyse d'haplotype du gène DM1 dans une population iranienne en santé. La dystrophie myotonique de type 1 (DM1) est due à une expansion instable d'une répétition CTG dans le gène DMPK (19q13.3). La répétition CTG est très polymorphe (de 5 à 37 répétitions) chez les sujets sains. En se basant sur l'hypothèse selon laquelle les allèles porteurs d'une expansion (CTG)n proviennent d'allèles normaux de grande taille, il pourrait exister une corrélation entre la prévalence de la DM1 et la fréquence des allèles normaux de grande taille. Un déséquilibre de liaison marqué entre des allèles de différentes tailles et trois marqueurs bisalléliques, Alu, Hinfl et Taq1 a été rapporté. Objectif : Le but de l'étude était de déterminer la distribution des allèles normaux ainsi que la fréquence des allèles normaux de grande taille et d'analyser ces trois marqueurs bisalléliques chez des sujets témoins iraniens en santé. Matériels et méthodes : La taille des allèles a été déterminée par réaction en chaîne de la polymérase (PCR) chez deux cents sujets iraniens en santé, non apparentés, appartenant à différents groupes ethniques vivant en Iran. Cent soixantequatorze chromosomes provenant de sujets témoins en santé ont été analysés par PCR/RFLP pour identifier les marqueurs. Résultats : Selon nos données, $23,7 \%$ des allèles avaient 5 répétitions CTG et 7,2\% des allèles avaient plus de 18 répétitions. L'analyse d'haplotype a montré que $75 \%$ des allèles porteurs de 5 CTG et $80 \%$ des allèles porteurs de plus de 18 CTG étaient également porteurs de l'haplotype (+++). Conclusion : La fréquence des allèles porteurs de plus de 18 CTG est semblable à celle qu'on retrouve en Europe de l'Ouest et au Japon.

Can. J. Neurol. Sci. 2008; 35: 216-219

Myotonic dystrophy type 1 (DM1) is an autosomal dominant disorder with an incidence of 1 in 8,000 births in Caucasian population. It is the most common form of muscular dystrophy in adults. The clinical features of this disease, though quite variable, are myotonia, muscle weakness and wasting, cataract, involvement of cardiac, smooth and respiratory muscles, endocrine insufficiency and frontal baldness. ${ }^{1}$ The genetic defect is caused by the unstable amplification of CTG trinucleotide repeats in the $3^{\prime}$-untranslated region of the protein kinase gene, DMPK, on chromosome $19 \mathrm{q} 13.3^{2}$ and the promoter region of the SIX5 gene. ${ }^{3}$ The CTG repeat number varies among healthy individuals from 5 to 37 and is stably transmitted from parents to children. Myotonic dystrophy type 1 patients have CTG repeat numbers from 38 to 4000 or more with remarkable variability in clinical symptoms and age-of-onset both between and within families. $^{2,4}$
It has been suggested that large normal alleles could be more unstable ${ }^{5}$ and that these larger alleles could serve as a reservoir for such mutations in expanded alleles of DM1 patients. ${ }^{6-8}$ Findings from human populations around the world indicate that the frequency of alleles with more than 18 repeats in a given

From the Genetics Research Center (BS, NM, KK, HN), University of Social Welfare \& Rehabilitation Sciences. Tehran, Iran; Molecular Diagnostic Unit (AMC), Hospital Donostia, San Sebastian, Spain.

Received August 30, 2007. Final Revisions Submitted January 9, 2008. Reprint requests to: Hossein Najmabadi, University of Social Welfare and Rehabilitation Sciences, Koodakyar St, Daneshjoo Blvd, Tehran, Iran, 19834 
population may show the prevalence of DM1 in that population. ${ }^{9}$ CTG repeats have also been reported to be useful in diagnosing cognitive deficits in DM1 patients as the blood CTG repeat expansion size correlates well with cognitive deficit in classical DM $1 .{ }^{10}$

Myotonic dystrophy type 1 has been reported to be more prevalent in Western Europe and Japan with an incidence of 2.25.5/100,000 and 5.5/100,000 respectively. ${ }^{11}$ Myotonic dystrophy type 1 is less prevalent in South-East Asians ${ }^{12}$ and is rare or absent in Southern and Central Africans. ${ }^{8}$ Myotonic dystrophy type 1 has been reported to be rare in a Middle East country, Kuwait. ${ }^{13}$ To the best of our knowledge, the prevalence of DM1 has not been reported in Iran. The aim of this study is to determine the number of (CTG)n repeats in the DM1 gene in 200 unrelated healthy Iranian individuals with no family history of DM1. According to the United Nations press, the Iranian population is divided into eight ethnic groups, as shown in Table 1. We collected our population sample according to the different Iranian ethnic groups which are genetically distinct depending on their geographic origin. Thus, our results are representative of the whole Iranian population.

Haplotype studies in the DM1 locus have been performed in different countries using three biallelic markers, including the 1 $\mathrm{kb}$ Alu insertion/deletion located in intron $8,{ }^{14} \mathrm{Hinf} 1 \mathrm{RSP}$ located in intron 9 and Taq1 RSP located $15 \mathrm{~kb}$ centromeric to the CTG repeats in the 3' UTR of the DMPK gene. Haplotype analyses have demonstrated a complete allelic association between DMcausing alleles and these markers. On the basis of these observations, it was proposed that all DM-causing alleles have a common origin possibly on a predisposing haplotype. ${ }^{15}$ These three markers and the linkage disequilibrium pattern among the latter led to a model for the CTG behavior given by Tishkoff et al. ${ }^{8}$ They suggested that the mid-sized alleles are the most ancient and higher and lower numbers of CTG repeats arose from these ancestral chromosomes. DM mutated alleles and $(\mathrm{CTG})>18$ share the same haplotype of Alu(+)-Hinf1(+)-taq1(+) which

Table 1: Demographic data of study group according to ethnicity

\begin{tabular}{lcc}
\hline Ethnic groups & Percent & Individuals* \\
Persian & $51 \%$ & 102 \\
Azeri & $24 \%$ & 48 \\
Gilaki \& & & \\
Mazandarani & $8 \%$ & 16 \\
Kurd & $7 \%$ & 14 \\
Arab & $3 \%$ & 6 \\
Others & $7 \%$ & 14 \\
Total & $100 \%$ & 200 \\
\hline
\end{tabular}

$* 50 \%$ male and $50 \%$ female

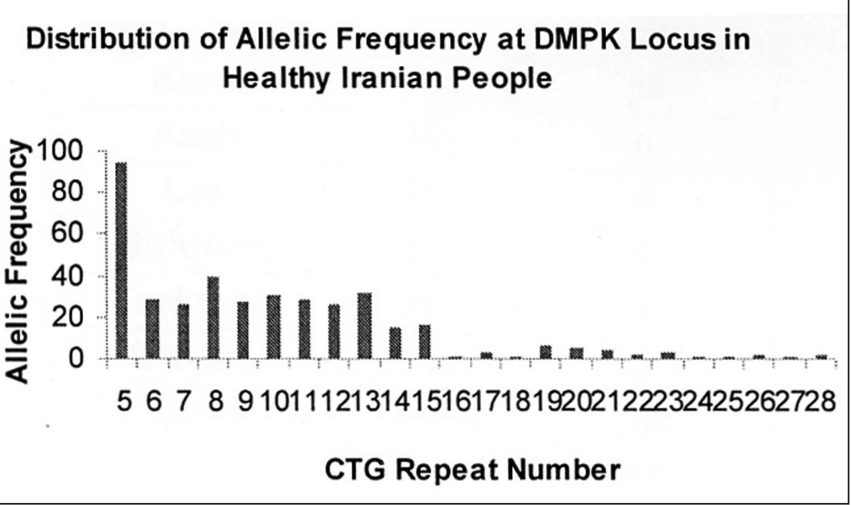

Figure: Distribution of allelic frequency at the DMPK locus in healthy Iranians.

indicates insertion of Alu repeats and existence of Hinf1 and Taq1 restriction sites. Thus, these expanded mutated alleles arose from alleles with more than 18 CTG repeats. ${ }^{15}$ Accordingly, we conducted a study on 174 other normal alleles according to the ethnicity described above to find the haplotype pattern in healthy Iranians.

\section{Materials ANd Methods}

After approving this study by the ethical committee at University of Social Welfare and Rehabilitation Sciences 200 unrelated healthy individuals with no family history of DM1 participated in this study. We collected our samples from healthy volunteers, the majority of them college students (informed consent forms obtained). Deoxyribonucleic acid (DNA) was extracted from peripheral blood leukocytes. We used polymerase chain reaction (PCR) with primers 96 and $102^{2}$ to amplify the region of the DMPK gene including the CTG repeat. The PCR products were separated on $8 \%$ polyacrylamide gels along side a 25-base pair standard DNA ladder. To estimate the size of the alleles, we used Lab Works TM Software (Version 4.0 for Windows).We also performed PCR/RFLP analysis of the three markers Alu, Hinf1 and Taq1 in a second distinct group of 174 control normal alleles including both parents of each sample in order to be able to analyze the results of Haplotype analysis. ${ }^{14,15}$

\section{RESULTS}

The analysis of 400 chromosomes showed 25 different allele sizes ranging from 5 to $28 \mathrm{CTG}$ repeats. Figure 1 shows the allelic frequency with peaks at 5,8 and 13 CTG repeats. Considering 18 repeats as a cutoff point, repeat sizes are divided into four subgroups according to the number of CTG repeats: 5, $6-8,9-17$, and $\geq 18 .{ }^{8}$ Alleles with five repeats were found among $23.75 \%$ of the study group. The subgroup with 9-17 CTG repeats was the largest subgroup of this study, which included 183 of the 400 chromosomes $(45.75 \%)$. The frequency of alleles with 18 or more repeats was $7.25 \%$, which falls within the Hardy-Weinberg equilibrium for this locus. The heterozygosity value is estimated 
Table 2: Association of (CTG)n frequency with observed haplotypes

\begin{tabular}{lccccc}
\hline Alu-Hinf1-Taq1 Haplotype & Frequency $(\%)$ & (CTG)5 & (CTG)6-8 & (CTG)9-17 & (CTG) $\geq 18$ \\
$(+++)$ & 40.23 & 74.32 & 0 & 12.19 & 80 \\
$(+--)$ & 1.15 & 1.36 & 0 & 1.1 & 0 \\
$(--+)$ & 2.88 & 2.7 & 0 & 3.3 & 0 \\
$(--)$ & 37.36 & 6.76 & 75 & 62.64 & 0 \\
$(-+-)$ & 4.02 & 2.7 & 25 & 4.4 & 0 \\
$(-++)$ & 12.64 & 9.46 & 0 & 14.29 & 20 \\
$(++-)$ & 1.72 & 2.7 & 0 & 1.1 & 0 \\
\hline
\end{tabular}

to be $92 \%$ using $1-\sum r^{2}$ where $r$ is the frequency of each single allele.

The result of $\chi^{2}$ analysis of these data in comparison with Europe, Japan, Southern Africa and Kuwait, a neighboring country of Iran in the Middle East shows that the frequency of the $\geq 18$ CTG repeat alleles in Iran is lower than in Japan $\left(\chi^{2}=0.367, \mathrm{P}=0.55\right)^{8}$ and in Europe $\left(\chi^{2}=1.76, \mathrm{P}=0.183\right)^{8,16}$ but it is significantly higher than that of Africa $\left(\chi^{2}=23.53, \mathrm{P}=0\right)^{7,13}$ and Kuwait $\left(\chi^{2}=5.06, \mathrm{P}=0.024\right) .{ }^{13}$ Significant differences between the allele frequencies of the Iranian and Kuwaiti populations were found for the CTG 9-17 subgroup $\left(\chi^{2}=0.312\right.$, $\mathrm{P}=0.58)$ but not for the CTG 5 subgroup $\left(\chi^{2}=0.918, \mathrm{P}=\right.$ $0.342) .^{13}$

The haplotype analysis of 174 alleles detected seven of the eight possible haplotypes of the three biallelic markers. The most frequent are (+++) and (---) that together account for $77.59 \%$ of the total. Haplotype $(+++)$ is strongly associated with CTG 5 $(74.32 \%)$ and CTG $>18$ (80\%), whereas haplotype (---) is strongly associated with CTG 6-8 (75\%) and CTG 9-17 $(62.64 \%)$. The distribution of the normal alleles in the 174 chromosomes ranges from 5 to 24 CTG and $42.53 \%$ of alleles have five repeats while $21.84 \%$ alleles have $12 \mathrm{CTG}$ repeats and $20.69 \%$ have 13 CTG repeats [Table 2].

\section{Discussion}

Myotonic dystrophy is an autosomal dominant disorder with a mean prevalence of 1 in 8,000 in several populations, excepting the two isolates in the Saguenay region of Québec ( 1 in 479) and in the Basque region of Spain (1 in 3800) which show the highest prevalence rates in the world. ${ }^{11,17,18}$ According to the haplotype analysis for Alu, Hinf1 and Taq1 markers, it has been suggested that $(\mathrm{CTG}) \geq 18$ alleles have arisen from the (CTG) 5 alleles, and that $(\mathrm{CTG}) \geq 18$ alleles could serve as a reservoir for new mutations, as such alleles may become unstable and expand to full mutation alleles, causing DM1. ${ }^{7}$ However, in African populations, large normal alleles with more than 18 repeats have arisen from (CTG)9-17 alleles. ${ }^{6,8}$ As a result, the distribution of the CTG repeats and their correlation with Alu, Hinf1 and Taq1 alleles may be different in different populations, which shows the origin of DM1 in a given population. ${ }^{8}$ Hence, it is necessary to determine the prevalence and the origin of DM1 in different populations.

The prevalence of DM1 in Iran is unknown, thus leading us to conduct this study to find the frequencies of normal alleles in the healthy population and thereby estimate the prevalence of DM1. The results of this study indicate that among the healthy Iranian population $7.25 \%$ of alleles are $(\mathrm{CTG}) \geq 18$, which is not low compared to those frequencies in Europe, Japan, Africa and Kuwait. In a study of the healthy Yugoslav population, $8.72 \%$ of alleles were $(\mathrm{CTG}) \geq 18\left(\chi^{2}=0.664, \mathrm{P}=0.418\right)$, very similar to our results. ${ }^{16}$ Although Kuwait, a neighboring country, showed low prevalence, Iran has a much higher frequency of alleles $(\mathrm{CTG}) \geq 18$, perhaps the result of the different ethnic groups that live in Iran.

The haplotype analysis of 174 chromosomes from healthy Iranians shows that the most common haplotypes are (+++) and (---) while (+--) is least observed [Table 2]. The (+++) haplotype is strongly associated with CTG 5 and CTG $>18$, while the (---) haplotype is associated with CTG 6-8 and CTG 9-17, similar to the results of haplotype studies in European countries. ${ }^{15}$

Therefore, the high frequency of large alleles in the healthy populations of both Iran and Europe, combined with the similarity in haplotypes, reinforces their similarities in the ancestral haplotype, the origin of the DM1 mutation, as well as the reservoir for recurrent DM mutations.

With such a debilitating effect, the determination of this high frequency of large alleles in the Iranian population should better guide health care authorities in Iran to adjust the level of attention to DM1 as a medical issue and consider prevalence study as a next step, and the importance of prenatal diagnosis for prevention as a national program. However, this requires the involvement of a multidisciplinary group of health care professionals with experience and dedication to the disease, which can only be achieved with the support and encouragement of the medical community.

\section{REFERENCES}

1. Harper PS. The Molecular Dystrophies. In: Scriver CR, Beaudet AL, Sly WS, Valle D, editors. Metabolic basis of inherited diseases. 6th ed. New York, NY: Mc Graw Hill Co; 1989. 
2. Brook JD, McCurrach ME, Harley HG, Buckler AJ, Church D, Aburatani $\mathrm{H}$, et al. Molecular basis of myotonic dystrophy: expansion of a trinucleotide (CTG) repeat at the 3 end of a transcript encoding a protein kinase family member. Cell. 1992; 68:799-808.

3. Boucher CA, King SK, Carey N, Krahe R, Winchester CL, Rahman $\mathrm{S}$, et al. A novel homeodomain in encoding gene is associated with a large $\mathrm{CpG}$ island interrupted by the myotonic dystrophy Unstable (CTG) n Repeat. Hum Mol Genet. 1995; 4:1919-21.

4. Martorell L, Monckton DG, Sanchez A, Lopez De Munain A, Baiget M. Frequency and stability of the myotonic dystrophy type 1 premutation. Neurology. 2001, Feb13; 56(3):328-35.

5. Waring JD, Korneluk RG. Genetic Studies of Myotonic Dystrophy CTG Repeat. In: Wells RD, Warren ST, editors. Genetic instabilities and hereditary neurological fiseases. San Diego: Academic Press. 1998: p. 131-46.

6. Zerylnick C, Torroni A, Sherman SL, Warren ST. Normal variation at the myotonic dystrophy locus in global human populations. Am J Hum Genet. 1995; 56:123-30.

7. Goldman A, Kamsay M, Jenkins T. New founder haplotypes at the myotonic dystrophy locus in southern Africa. Am J Hum Genet. 1995; 56:1373-8

8. Tishkoff SA, Goldman A, Calafell F, Speed WC, Deinard AS, Bonne Tamir B, et al. A global haplotype analysis of the myotonic fystrophy locus: Implications for the evolution of modern humans and for the origin of myotonic fystrophy Mutations. Am J Hum Genet. 1998; 62:1389-402.

9. Watkins WS, Bamshad M, Jorde LB. Population Genetics of trinucleotide repeat polymorphisms. Hum Mol Genet. 1995; $4: 1485-91$.

10. Winblad S, Lindberg C, Hansen S. Cognitive deficits and CTG repeat expansion size in classical myotonic dystrophy type1(DM1). Behav Brain Funct. 2006; 2:16.
11. Davies J, Yamagata H, Shelbourne P, Buxton J, Ogihara T, Nokelainen P, et al. Comparison of the myotonic dystrophy associated CTG repeat in european and Japanese populations. J Med Genet. 1992; 29:766-9.

12. Ashizawa T, Epstein HF. Ethnic fistribution of the myotonic dystrophy gene. Lancet. 1991; 388:642-3.

13. Alfadhli S, Kaaba S, Elshafey A, Salim M, AlAwadi A, Bastaki L. CTG repeat number at the myotonic dystrophy locus in healthy Kuwaiti individuals. Arch Neurol. 2004; 16:895-8.

14. Mahadevan MS, Foitzik MA, Surh LC, Korneluk RG. Characterization and polymerase chain reaction (PCR) detection of an Alu deletion polymorphism in total linkage disequilibrium with myotonic dystrophy. Genomics. 1993; 15:446-8.

15. Neville CE, Mahadevan MS, Barcelo JM, Korneluk RG. High resolution genetic analysis suggests one predisposing haplotype for for the origin of the myotonic dystrophy mutation. Hum Mol Genet. 1994; 3:45-51.

16. Culjkovic B, Stojkovic O, Vukosvic S, Savic D, Rakocevic V, Apostolski S, et al. CTG repeat polymorphism in DMPK gene in healthy Yugoslav population. Acta Neurol Scand. 2002; 105: 55-8.

17. Lopez de Munain A, Blanco A, Emparanza JI, Poza JJ, Martí-Massó JF, Cobo AM, et al. Prevalence of myotonic dystrophy in Guipuzcoa (Basque Country, Spain). Neurology. 1993; 43:1573-6.

18. Mathieu J, De Braekeleer M, Prevost C. Genealogical reconstruction of myotonic dystrophy in the Saguenay-Lac-SaintJean area (Quebec, Canada). Neurology. 1990 May; 40(5): 839-42. 